\title{
Kharif Fallow utilization for Groundwater Recharge
}

\author{
Shobhana Bisen $^{1 *}$, Preeti Choudhary ${ }^{2}$, M. K. Awasthi ${ }^{3}$ and Deepak Patle ${ }^{3}$ \\ ${ }^{1}$ Department of Irrigation and Drainage Engineering, MPKV, Rahuri, Maharastra, India \\ ${ }^{2}$ Department of Irrigation and Drainage Engineering, GBPUAT, Pantnagar, \\ Uttrakhand, India \\ ${ }^{3}$ Department of Soil and Water Engineering, JNKVV, Jabalpur, Madhya Pradesh, India \\ *Corresponding author
}

\section{A B S T R A C T}

Ground water withdrawal for irrigation, if not done correctly, leads to falling water table below critical level. In Madhya Pradesh, out of 313 blocks, 23 blocks extended to over exploited category, 09 blocks are in critical stage and 57 blocks are in semi critical stage (MP Dynamic Ground Water Assessment, 2015). As per rules of CGWB, the areas where the water level could not recuperated upto $3 \mathrm{~m}$ depth after the monsoon

Keywords

Groundwater recharge, Kharif fallow, Priority

\section{Article Info}

Accepted: 04 November 2019 Available Online: 10 December 2019 season, will essential artificial recharge. The solution lies in harvesting rainwater in farmers' field which are kept or left fallow for one reason or another. Though, all these fields may not be good enough to recharge groundwater like percolation tanks but transfer water well below at least @ $4 \mathrm{~mm} /$ day even in clayey soils. So, to decide which area is to be taken first in present study a method of identification of priority is proposed. Four basic criteria to decide the priority namely, amount of annual rainfall, the soil type, stage of ground water development stage and extent of kharif fallow. Each of these four category are subdivided into four sub classes and giving grades from $\mathrm{A}$ to $\mathrm{D}$ where $\mathrm{A}$ is top in that particular category. Thus an area which attains all four 'As' in all four category will have a score ' 4 ' as qualifies as top priority area. Based on above methodology the rank table is prepared. There are 11 blocks comes under 1st priority which needs immediate action towards ground water recharge. Those blocks are Pansemal Rajpur (Barwani), Dewas (Dewas), Badnawar, Dhar, Darampuri, Nalchha (Dhar), Sitamau, Mandsaur (Mandsaur), Sujalpur (Shajapur), Ujjain (Ghatiya). These blocks of 5 districts (Barwani, Dewas, Mandsaur, Shajapur, Ghatiya) needs more attention for Ground water recharge.

\section{Introduction}

Agriculture is the main stay of the people of Madhya Pradesh State. Water is essential for irrigation purposes, but its indiscriminate use can lead not only to shortages, but also to the deterioration of crop yields and soils. Ground water resource of a region is one of the building blocks for balanced economic development of the area, especially in an 
agriculture based society. Dependence on ground water for irrigation and increasing water requirements in urban areas in Madhya Pradesh has necessitated judicious and planned uses of ground water resources in order to reach sustainability. For proper planning and management of ground water development in a judicious and socioeconomically equitable manner, assessment of ground water scenario is one of the most important prerequisites.

Only a small fraction of water available for use of mankind in India, agriculture sector utilize more than $2 / 3 \mathrm{rd}$ of water which is slightly to reduce due to rapid development pace of industrialization. Even on full development of irrigation potential, there will remain $1 / 3$ re area as un irrigated. Groundwater is the major water resource being utilized for irrigation; therefore replenishment must be ensured.

The North Central Region office of Central Ground Water Board, based at Bhopal, monitor the ground water wells spared all over the state.

As on start of the year i.e. 31-03-2015, the number of ground water monitoring well is 1482 which includes 1134 dug wells and 348 piezometers. During the year some new additional dug wells were established. Few of the exiting dug wells and Piezometers were declared as abandoned.

At the close of the Year i.e. 31-03-2016, the number of ground water monitoring well is 1487 which includes 1161 dug wells and 326 piezometers. All stations are monitored four times in a given hydrological year in the months of August (20st to 30th day), November (post monsoon) (1st to 10th day), January (1st to 10th day) and May (pre monsoon) (20th to 30th day). The long-term data generated during these monitoring seasons are important for computation, comparison and analysis of ground water utilization and its availability.

\section{Materials and Methods}

\section{Study area}

Madhya Pradesh is located in the central part of India and is a land-locked State, bordered on the west by Gujarat, on the northwest by Rajasthan, on the northeast by Uttar Pradesh, on the east by Chhattisgarh, and on the south by Maharashtra. It has a geographical area of $3,08,252 \mathrm{~km} 2$ and is situated between north latitudes $21^{\circ} \quad 04^{\prime}$ and $26^{\circ} \quad 54^{\prime}$ and east longitudes $74^{\circ} 00^{\prime}$ and $82^{\circ} 50^{\prime}$. There are 51 districts and 313 Community Development blocks in Madhya Pradesh. The population of State as per census 2011 is 7, 25, 97, 565 with a population density of 236 persons per $\mathrm{Km}^{2}$ area. Out of total population, $75 \%$ lives in the villages and their main occupation is agriculture. The important urban areas in the State are Bhopal, Indore, Jabalpur, Ujjain and Gwalior. Dhupgarh in Pachmarhi is the highest point in the State.

\section{Data collection}

We have taken a data from the "Assessment Of Dynamic Groundwater Resource Of The Madhya Pradesh (as on march 2015)".

As the data of kharif fallow land is available only for the districts, but for this project we need block wise data so we have followed "geo-proportionate" process in order to determine the required data.

The calculation is illustrated as below

Kharif fallow area of block

$$
=\text { Geographical area of block } \times \frac{\begin{array}{c}
\text { Kharif fallow of } \\
\text { that district }
\end{array}}{\begin{array}{c}
\text { Total geographical } \\
\text { area of district }
\end{array}}
$$

To start with, this exercise of utilization of 
fallow land for water harvesting shall be followed in priority basis. In current study a method of identification of priority is suggested. Four basic criteria to choose the priority area, amount of annual rainfall, the soil type, stage of ground water development and extent of kharif fallow. Each of these four categories are decided into four sub classes and giving grades from A to D where A is top prioritization in that particular category. Thus an area which attains all four 'As' in all four categories will have a score of ' 4 ' and qualifies as top priority area. Table 1 illustrates all categories, sub-classes and grades. Block which get minimum priority score is 5, indicates first priority and maximum priority score is 15 indicate last priority i.e. $11^{\text {th }}$ priority. Digitization of district map of Madhya Pradesh through the Arc Map 10.3 and spatially variability priority map of Madhya Pradesh are developed (Fig. 1 and 2).

Fig.1 Location of the study area

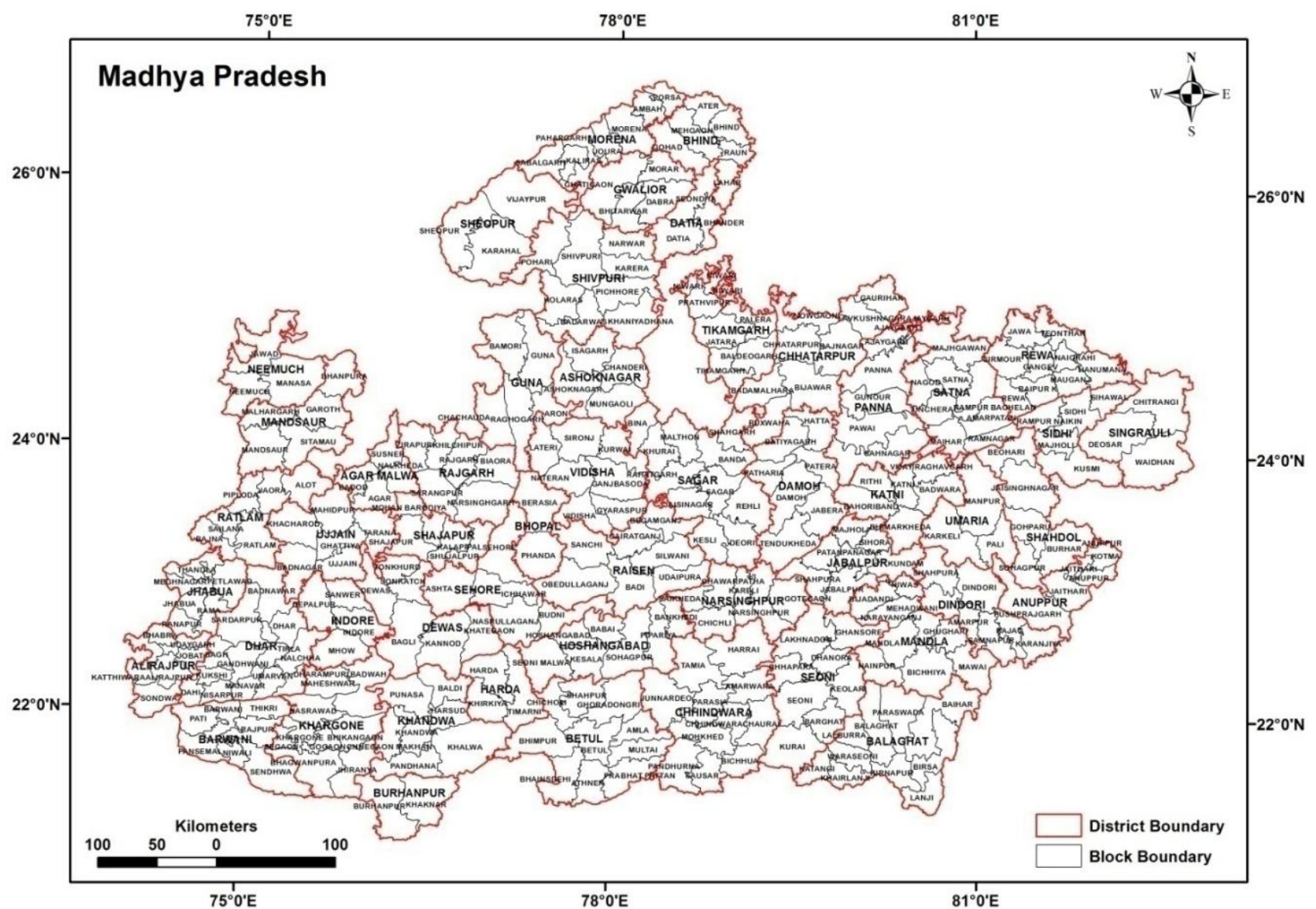

\section{Results and Discussion}

In order to determine priority of blocks for rain water harvesting, soil type, rainfall, kharif area and ground water tapping percentage of blocks were kept in mind. These are shown in Table 2 in different groups (A, B, C, D). 'A' class represents first priority \& ' $D$ ' class represents final priority and on this basis, total score were calculated by giving them score from 1 to 4 . Block which get minimum priority score is 5 , indicates 1 st priority and maximum priority score is 15 indicate last priority i.e. $11^{\text {th }}$ priority. 
From all the above assessment we have done, we have developed a priority table, which shows that on which block we have to primarily implement groundwater recharge technique so as a consequent of which we get more and more profit by using less resources, less initial cost and less investment.

Any kind of water storage is ground water recharge which will be helpful in stopping the falling ground water level. If rainwater harvesting is made in farm itself, then there will be a significant reduction in dependency on other measures of artificial ground water recharge. At least 2400 cubic meters of ground water recharge is also possible in the average rainfall by the soil having minimum infiltration rate.

Table.1 Category of basic criteria for score

\begin{tabular}{|c|c|c|c|c|c|}
\hline \multirow{2}{*}{$\begin{array}{l}\text { S. } \\
\text { No }\end{array}$} & \multicolumn{4}{|c|}{ Categories } & \multirow{2}{*}{$\begin{array}{c}\text { Score of } \\
\text { each } \\
\text { category }\end{array}$} \\
\hline & $\begin{array}{c}\text { Normal } \\
\text { Rainfall(mm) }\end{array}$ & $\begin{array}{c}\text { Ground Water } \\
\text { Development }(\%)\end{array}$ & Soil Type & $\begin{array}{c}\text { Kharif Fallow } \\
\text { (ha) }\end{array}$ & \\
\hline 1. & $700-900$ & $\begin{array}{c}\text { Over Exploited } \\
>100 \%\end{array}$ & Deep Medium Black Soil & $<1000$ & 1 \\
\hline 2. & $900-1100$ & Critical 90-100\% & Loam Soil & $1000-5000$ & 2 \\
\hline 3. & $1100-1300$ & $70-90 \%$ & Red \& Black Soil & $5000-10000$ & 3 \\
\hline 4. & $>1300$ & $<70 \%$ & Shallow \& Medium Black Soil & $>10000$ & 4 \\
\hline
\end{tabular}

Fig.2 Priority block map through kharif fallow

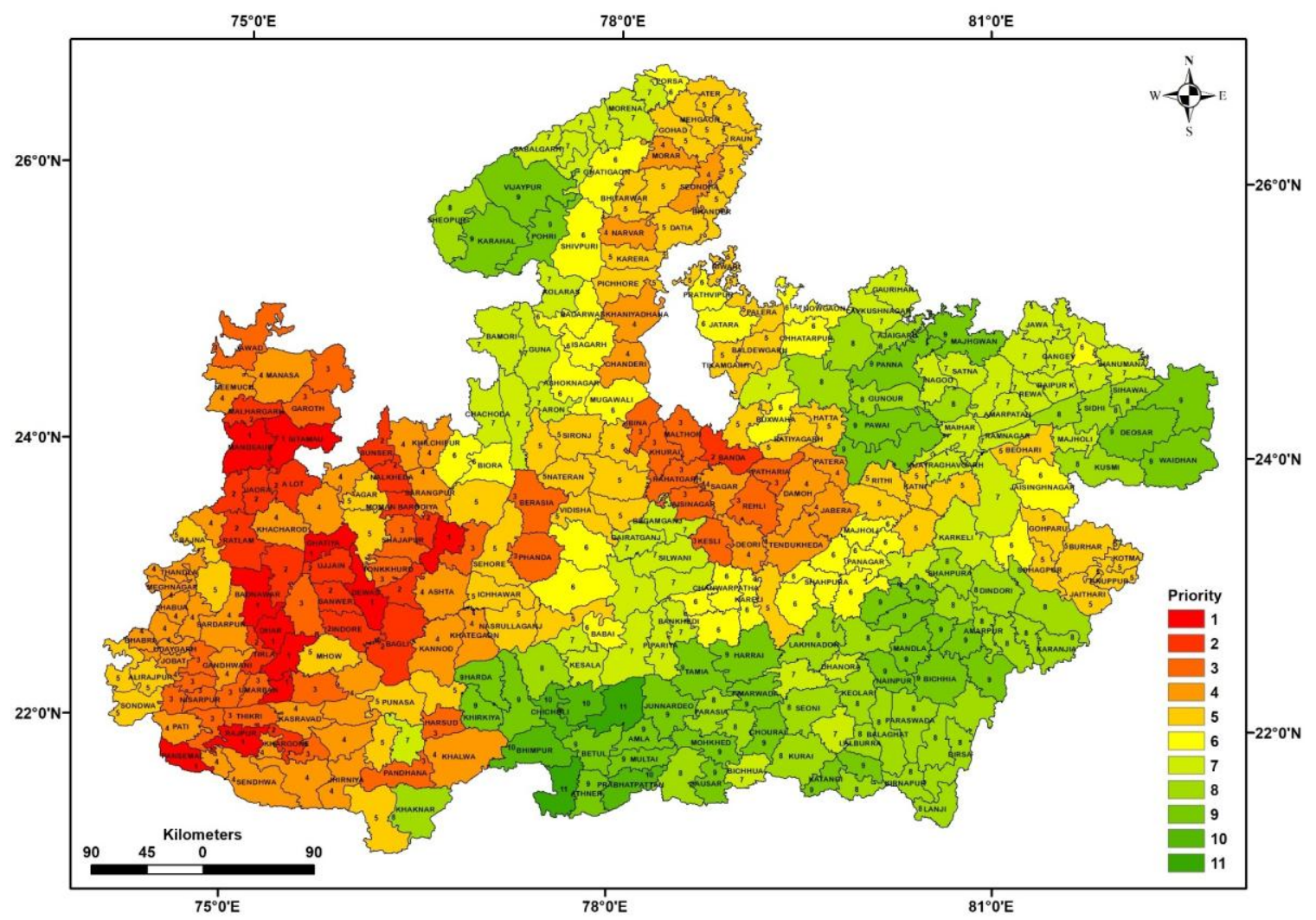


Table.2 Priority blocks of Kharif fallow for ground water recharge

\begin{tabular}{|c|c|c|c|}
\hline S.No. & Priority Score & No. of blocks & Name of Blocks \\
\hline 1. & 1 & 11 & $\begin{array}{c}\text { Badnawar, Dewas, Dhar, Darampuri, Ghatiya, Mandsaur, } \\
\text { Nalchha, Pansemal, Rajpur, Shujalpur, Sitamau }\end{array}$ \\
\hline 2. & 2 & 17 & $\begin{array}{c}\text { Alot, Badnagar, Bagli, Banda, Indore, Jaora, Khargone, } \\
\text { Malhargarh, Moman-barodiya, Nalkheda, Piploda, } \\
\text { Ratlam,Sanwer, Sonkatch, Sunser, Tirla, Ujjain }\end{array}$ \\
\hline 3. & 3 & 29 & $\begin{array}{l}\text { Bagh, Barwani, Berasia, Bhanpur, Bina, Dahi, Depalpur, } \\
\text { Garoth, Gogaon, Harsud, Jaisinagar, Jawad, Kalapipal, } \\
\text { Kesli, Khurai, Kukshi, Maheshwar, Maithon, Manavar, } \\
\text { Nisarpur, Pandhana, Patharia, Phanda, Rahatgarh, Rehli, } \\
\text { Shajapur, Thikri, Tonkkurd, Umarban }\end{array}$ \\
\hline 4 & 4 & 42 & $\begin{array}{l}\text { Asta, Badod, Badwah, Bhabra, Bhagwanpura, } \\
\text { Bhikangaon, Damoh, Deori, Gandhwani, Jabera, Jhabua, } \\
\text { Jhirniya, Jobat, Kachrod, Kannod, Khalwa, } \\
\text { Khaniyadhana, Khategaon, Khasravad, Khilchipur, } \\
\text { Mahidpur, Manasa, Meghnagar, Morar, Narvar, } \\
\text { Neemuch, Niwali, Patera, Pati, Rama, Ranapur, Sagar, } \\
\text { Sailana, Sarangpur, Sardarpur, Segaon, Sendhwa, } \\
\text { Seondha, Tendukheda, Thandla, Udaygarh, Zirapur }\end{array}$ \\
\hline 5 & 5 & 56 & $\begin{array}{l}\text { Agar, Alirajpur, Anuppur, Ater, Badwara, Bajna, } \\
\text { Baldewgarh, Baldi, Batiyagarh, Beohari, Bhander, } \\
\text { Bhind, Bhitarwar, Bhoriband, Budani, Burhanpur, } \\
\text { Burhar, Chhegaonmakhan, Dabra, Datia, Dhimarkheda, } \\
\text { Ganjbasoda, Gohad, Gohparu, Gyaraspur, Hatta, } \\
\text { Ichhawar, Jaithari, Krera, Katni, Katthiawara, Kotma, } \\
\text { Kurwai, Lateri, Lahar, Mehgaon, Mhow, Narsinghgarh, } \\
\text { Narsingpur, Nasrullaganj, Nateran, Niwari, Palera, } \\
\text { Petlawad, Pichhore, Punasa, Raun, Rithi, Sehore, } \\
\text { Shahgarh, Sironj, Sohagpur, Sondwa, Tarana, } \\
\text { Tikamgarh, Vidisha }\end{array}$ \\
\hline 6 & 6 & 32 & Ashoknagar, Babai, Badarwas, Biora, Buxwaha, \\
\hline
\end{tabular}




\begin{tabular}{|c|c|c|c|}
\hline & & & $\begin{array}{l}\text { Chanderi, Chanwarpatha, Chhatarpur, Chichli, } \\
\text { Ghatigaon, Gotegaon, Isagarh, Jabalpur, Jaisinghnagar, } \\
\text { Jatara, Kareli, Majholi, Mugawali, Naigarhi, Nowgaon, } \\
\text { Obedullaganj, Pali, Panagar, Patan, Porsa, Prathvipur, } \\
\text { Rajgarh, Saikheda, Sanchi, Shahpura, Shivpuri, Sihora }\end{array}$ \\
\hline 7 & 7 & 49 & $\begin{array}{c}\text { Amarpatan, Ambah, Aron, Badamalahara, Badi, Bamori, } \\
\text { Bankhedi, Barghat, Begamganj, Bichhua, Chachoda, } \\
\text { Chapara, Dhanora, Gairatganj, Gangev, Gaurihar, Guna, } \\
\text { Hanumana, Hosangabad, Jawa, Joura, Kailaras, Karkeli, } \\
\text { Kesala, Khandwa, Kolaras, Kundam, Luvkushnagar, } \\
\text { Mahjholi, Maihar, Manpur, Mauganj, Morena, Nagod, } \\
\text { Pahargarh, Pipariya, Raghogarh, Raipur k, Ramnagar, } \\
\text { Rampur Baghelah, Rewa, Sabalgarh, Satna, Sirmour, } \\
\text { Silwani, Sohagpur, Teonthar, Udaipura, } \\
\text { Vijayraghavgarh. }\end{array}$ \\
\hline 8 & 8 & 36 & $\begin{array}{l}\text { Ajaigarh, Amarpur, Baihar, Bajag, Balaghat, Bijawar, } \\
\text { Birsa, Chhindwara, Dindori, Ghansore, Gunour, } \\
\text { Karanjia, Keolari, Khairlangi, Khaknar, Kirnapur, Kurai, } \\
\text { Kusmi, Lakhnadon, Lalburra, Lanji, Mehandwani, } \\
\text { Pandhurna, Parasia, Paraswada, Pusprajgarh, Rajnagar, } \\
\text { Rampur-Naikin, Samnapur, Seoni, Seonimalwa, } \\
\text { Shahpura, Sheopur, Sidhi, Sihawal, Unchera. }\end{array}$ \\
\hline 9 & 9 & 35 & $\begin{array}{l}\text { Amarwasa, Amla, Athner, Betul, Bichhia, Bijadandi, } \\
\text { Chitarangi, Chourai, Deosar, Ghughri, Harda, Harrai, } \\
\text { Junnardeo, Karahal, Katangi, Khirkiya, Majhgwan, } \\
\text { Mandla, Mawai, Mohgaon, Mohkhed, Multai, Nainpur, } \\
\text { Narayanganj, Niwas, Panna, Pawai, Pohri, Sahnagar, } \\
\text { Sausar, Tamia, Timarni, Vijaypur, Waidhan, Waraseoni. }\end{array}$ \\
\hline 10 & 10 & 4 & Bhimpur, Chicholi, Prabhatpattan, Shahpur. \\
\hline 11 & 11 & 2 & Bhainsdehi, Ghoradongri. \\
\hline
\end{tabular}




\section{Acknowledgment}

Authors thankfully acknowledge to Dr. M.K. Awasthi, Professor, Department of Soil and Water Conservation Engineering, College of agricultural engineering (JNKVV), Jabalpur (M.P.) for his valuable gratuity supervision guidance and encouragement and the knowledge he shared with us during the due course of our project. Thanks to Er. Deepak Patle for helping us being available in all circumstances and guiding us when we need most.

\section{References}

Anonymous. 2018. AICRP Annual Report 2017-18. Department of Soil and Water Engineering. College of Agricultural Engineering, JNKVV, Jabalpur, Madhya Pradesh

Anonymous. 2017. Annual Report 2016-17. Commissioner Land Records, Madhya Pradesh.

Anonymous. 2016. Annual Report 2015-16. Directorate of Extension, Madhya Pradesh.

Awasthi, M.K. and Patle, Deepak. 2019. Water harvesting in kharif fallow for augmenting ground water recharge. $4^{\text {th }}$ InternationalConference on Soil and Water Resources Management for Climate Smart Agriculture, Global Food and Livelihood Security. Soil Conservation Society of India, New Delhi. November 5th-9th, 2019. Abstract book, Page No. 94.

Dynamic Ground Water Assessment. 2015.

Water Resources Development of Madhya Pradesh. http://www.mpwrd.gov.in/dynamicgw-assessment-2015.

GEC. 1997. Ground Water Estimation Methodology. Groundwater Estimation Committee Ministry of Water Resource, Government of India, New Delhi.

Ground Water Year Book. 2015. Central Ground Water Board, North Central Region, Bhopal, Madhya Pradesh. http://cgwb.gov.in/Regions/GW-year-

Books/GWYB-201415/GWYB\%202014-15-MP.pdf

Haveli System: A Promising Technique for Ground Water Recharge. 2015. Department of Soil and Water Engineering. College of Agricultural Engineering, JNKVV, Jabalpur, Madhya Pradesh

\section{How to cite this article:}

Shobhana Bisen, Preeti Choudhary, M. K. Awasthi and Deepak Patle. 2019. Kharif Fallow utilization for Groundwater Recharge. Int.J.Curr.Microbiol.App.Sci. 8(12): 284-290. doi: https://doi.org/10.20546/ijcmas.2019.812.039 